\title{
Lost, found, and omitted: Remarks on Russian translations of West European literature
}

\section{OLGA SIDOROVA}

DOI: https://doi.org/10.31577/WLS.2021.13.3.9

There is little doubt that a body of texts of fiction translated from different languages makes an inseparable and influential part of every national literary and cultural background. It is also obvious that this body is not invariable since, new translations constantly appear - their interrelations with other translations, as well as with national texts of fiction become complicated and interwoven.

In his L'Épreuve de l'étranger (1984; The Experience of the Foreign, 1992) Antoine Berman claims that the first aim of contemporary translation theory is to write translation history. What is more, he stresses that in every historic period translation practice influences the target literature and culture, though differently in any particular case. However, as Itamar Even-Zohar has emphasized, "there is no awareness of the possible existence of translated literature as a particular literary system" ([1990] 2004, 199).

The objective of this article is to suggest a perspective on the history of foreign, mainly West European literary translations into Russian where not only translated works of literature, but first and foremost, those which remained untranslated due to different reasons are also taken into consideration. The history of translation of West European literature into Russian is long, and it has been studied in detail. However, we claim that translation history embraces not only translated books, but also the ones that were omitted from translation, thus creating "gaps" which are significant factors of cultural discord. Translation history in its broader sense can be said to embrace both translated and not-translated books and authors, since the presence and/or absence of a foreign book in a target literature can be equally significant. The reasons and the consequences of translation/non-translation are various, as examples from Russian translation history will show. The analysis presented is mainly based on translation of Anglophone literatures, though references to different authors are also made.

\section{LITERARY TRANSPLANTATION: GENERAL INSIGHTS}

Foreign literature in Russian translation has always been and is still popular with publishers and the reading public. Even today, when English has become the language of global communication, and books in English are easily available around the world, Russian is still the fourth language engaged in translation globally (Bellos 
2011, 246). The history of Russian literature and the role translations have played in it have been studied by a number of scholars. Academician Dmitry Likhachev writes about "literary transplantation" in Razvitiye russkoi literatury X-XVII vekov (Development of Russian literature in the 10th-17th centuries, 1973). Speculating about the Old Russian literature, which during its early period was almost fully constructed of different Byzantine texts in translation, he states that literary texts "were transferred, transplanted onto a new ground, where they started living independently in a new surrounding [...]. A new cycle of their development started in a new historic environment, [they] changed, adapted, acquired local features, were filled with new contents and developed new forms" (78). ${ }^{1}$ The result of the specific influence was productive development of the Old Russian literature along its own path.

The idea of literary transplantation was further developed by Yuri Lotman in several works mostly in the late 1970s-1980s. In his articles on the typology of cultures (1992a) and on the theory of interaction between cultures (1992b), Lotman mentions different periods in the history of European literature when numerous unidirectional translations made powerful impacts onto recipient literature and made it develop in its own specific way. That was the case with the Ancient Roman literature that was inspired by the Ancient Greek literature. Similar cases can be seen in histories of other national literatures, for example, in some "small" literatures of the former Soviet republics. Lotman outlines two periods in Russian literary history when translated texts of fiction were productively transplanted on a mass scale onto the local soil - the first one was described by the already mentioned Likhachev and related to the Byzantine books translated into Russian. The second period is related to the West European impact on life in Russia in the 18th century. The openness-to-the-West policy proclaimed by Peter I and followed by his successors resulted in huge transformations in many spheres. At the beginning of the period, texts of fiction in translation were viewed as models not only for a newly developing secular literature (as opposed to the previously central religious literature), but its modes and characters were often viewed as modes to follow in real life. Having analyzed the role of translated literature in the Russian life of the period, Lotman shows that problems of meaning were often problems of translatability.

One of the most interesting examples of translated books of the period was a free translation of Paul Tallemant's novel Le voyage à l'île d'Amour made by Vasily Trediakovsky in 1730 that became the first contemporary Western novel translated into Russian. As Lotman stated, although a book of modest merits and only one of many novels in French literature, it became unique in Russian: "Being transplanted from its French cultural context and put into Russian, it [...] changed both its meaning and cultural function [...]. It was torn apart from its natural cultural context [...] and became an isolated text, closed in itself" (1992c, 225). ${ }^{1}$ At the same time, both Trediakovsky himself and his Russian readers took it as an instruction, since it described "normative behavior of a person in love, [...] lovers' roles" (222), and presented the language of feelings. The French gallant culture was a form of art, artificial in many ways - having been transplanted into Russian life, it made a powerful impetus to develop new culture. Lotman makes the following conclusion: "In the original 
situation of the French gallantry, the very cultural environment gave rise to novels of a certain type, while in translation the novel's text was expected to create adequate cultural environment" (227). The reading public eagerly appropriated Western modes - in the middle of the 18th century Russian readers were happily reading many European novels in translation, and by the end of the 18th century, the first Russian books of fiction became popular. Not long afterward, in the early 19th century, Russian literature reached its heights.

Yuri Lotman also showed that such "transplantation periods" were usually comparatively short - they were fast followed by the rise of national literatures. At the initial stage, center-periphery literary relations were mostly unilateral, but they clearly changed when the recipient literature (Russian in our case) reached a certain level of development. In the 19th and 20th centuries, Russian and later on Soviet culture, literature, public and the state itself (in different forms) were actively involved in making decisions on what books were to be translated. The direct or indirect state interference in translation choices is not infrequent in translation history. More subtle cases are more interesting, revealing much about the state of the society and culture, that are ready to accept or reject new values, forms and ideas. As Berman points out, each culture is in resistance to translation, since cultures are ethnocentric (1984, 92-93). The very aim of translation is to meet the Other, to disclose inherent links with a different culture, and to enrich one's native literature with the help of the alien one.

\section{LITERARY TRANSLATION/NON-TRANSLATION INTO RUSSIAN IN THE 19TH CENTURY: THE JANE AUSTEN IN RUSSIAN CASE}

According to Ljudmila Volodarskaya (2003), a literary interaction is impossible without two factors that are to coincide at a certain historic moment: one nation creates some literary text of value that another nation is predisposed to accept or to reject. The famous Russian poet and translator Boris Pasternak has supported the point, claiming translation to be not just rendering of separate books or texts into a foreign culture, but rather nations and cultures encountering $(2004,52)$. If this is the case, then translation/non-translation is vastly determined by the fact of the target culture interest in a particular author or work of literature, not just in its plot, but rather in its existential and metaphorical meaning. Alternatively, "the degree to which the foreign writer is accepted into the native system will [...] be determined by the need of the native system in a certain phase of its evolution" (Lefevere [1982] 2004, 243).

The case of 19th-century Russian literary translation presents numerous examples proving this point. First, the leading writers of the period - Nikolay Karamzin, Vasily Zhukovsky, Alexander Pushkin, Ivan Turgenev, Leo Tolstoy and others - were multilingual (sometimes we can observe it in their works - see Tolstoy's French inclusions into his War and Peace) and translated books of fiction from many languages. Starting from the late 18th century, Russian periodicals were constantly publishing West European literature in translation. By the mid-19th century, the tendency reached its peak - almost every prominent French, German or English author was well-known to Russian readers; their new works were reviewed and translated. The leading jour- 
nals of the period - Sovremennik, Otechestvennyje zapisky and others - used to publish lengthy reviews devoted to different national literatures. For example, a series of reviews entitled "Letters from a distant subscriber about English literature and journalism" by Alexander Druzhinin recurrently appeared in Sovremennik from 1852 to 1856. Chapters from various novels by Charles Dickens were immediately translated into Russian and published only months after their English release. Irinarkh Vvedensky, a well-known Dickens translator, was in correspondence with the English author himself. The contemporary critic Henry Gifford claims that in Russia, from the very beginning Dickens enjoyed "the same phenomenal success as at home or in the United States" $(2015,47)$. According to Gifford, "no foreign writer of that time (or since) ever became so thoroughly domiciled in the Russian imagination" (51).

Though Dickens was the most popular English writer with Russian readers, other writers were also widely translated, loved, and respected - with some exceptions, though. It might sound strange, but Jane Austen was totally absent from the English literary map of the Russian 19th century. The translation and reception history of Jane Austen's novels in Russia is a very special case. As Catharine Nepomnyashchy states, "the posthumous response to Austen's works across Europe has followed a rough pattern of discovery and appreciation by an educated elite and later adoption by a popular audience. This has made Austen's reception a bellwether for rival claims both by keepers of high culture and devotees of mass culture" $(2007,345)$. Yet the pattern was different in Russia - mostly due to the late translation of the author's works into Russian in the late 20th century.

In the early 19th century, Austen's works were obviously known to Russian critics. In 1816, for example, an article appeared in Vestnik Evropy journal. A release of the writer's new book Emma was advertised in the article: "Emma, a novel by the author of Sense and Sensibility; Pride and Prejudice, 3 vols. [...]. An anonymous lady-writer beautifully depicts quiet family life" (Anonymous 1816, quoted in Nepomnyashchy 2007, 322). Several points are of interest here: the Russian article was published immediately after the book appeared in English; besides, the reviewer was clearly acquainted with Austen's earlier novels. Interestingly enough, the title page of the first edition of Emma mentions that it is "by the author of Pride and Prejudice" (319). The other novel Sense and Sensibility is not mentioned there. Thus, the reviewer definitely knew Austen's books and recommended them to Russian readers. In the article, Austen's works were mentioned in the context of women's writing - other women authors were named, the most outstanding of whom, according to the critic, was Mary Edgeworth. No doubt, Edgeworth's novels were popular with readers; they appeared in Russian journals in different translations, some of them being made by a famous Russian poet and translator Vasily Zhukovsky. But Austen's works did not attract any attention from translators.

The next time Austen's name appeared in a Russian journal was forty years later, in Otechestvennyie zapiski in 1854. The eminent critic and translator, Aleksandr Druzhinin, mentions her name among the names of other English women-writers and calls "Miss Austen" an example to be followed (quoted in Nepomnyashchy 2007, 337). The author's name was mentioned in the same journal and in the same context 
of women's literature in 1871 , for the last time in the 19th century. The prominent literary critic Maria Tsebrikova was also a well-known political activist. She supported opposition to the Tsarist regime and fought for women's emancipation. In her article about English women writers Tsebrikova voiced her disapproval of Jane Austen's works: "An endless string of superbly long, morally instructive and dignified novels with very moderate romance turns appeared [...]" (quoted in Nepomnyashchy 2007, 337). In this description a reader could recognize a hidden quotation from Pushkin's "Count Nulin" poem, where the heroine is reading "a sentimental novel / Love of Eliza and Arman, / the correspondence of two families [...] the novel classical and old / wonderfully long, a long, a long / peachy and sedate / without romantic turns" (1963, 242), but gets bored and is distracted by a fight between a goat and a watchdog. As early as 1828 , Pushkin ridiculed novels of that kind as obsolete - but Tsebrikova applied his critical description to Jane Austen's works in the 1870s. Why was she so critical towards the works of the English author? Presumably, Austen's novels did not coincide with the reviewer's position of a fighter for women's rights; what is more, they did not fit into the mainstream literary trends of the period in Russia. They did not present a broad panorama of life or sharp social conflicts. Compared to other novels of the period, they had little action, were not so straightforward and pathetic, full of irony and free indirect speech. Presumably the reason why Russian translators of the 19th century skipped Austen's novels is because their preferences were different.

Overall, starting from the 1840s onward, literary translation in Russia was increasingly involved in the democratic revolutionary movement, as shown in Yuri Levin's Russkiye perevodchiki XIX veka (Russian literary translators of the 19th century, 1985). The very choice of books for translation was significant. At the beginning of his career one of the leading poetry translators of the mid-19th century, Mikhail Mikhailov considered translation the means of cultural exchange, but later he fully dedicated his work to revolutionary propaganda. Mikhailov's translations of the early 1860 s included many poems containing sharp social critique ("Enfant perdu", "Weltlauf", "Jammerrthal" and others by Heinrich Heine; "Peace to the Slumberers" by Thomas Moore); poems where slavery, imprisonment and exile were sympathetically described, e.g. Poems on Slavery by Henry W. Longfellow, "The exile" by Thomas Hood, "The Song of a Felon's Wife" by Barry Cornwall, etc. Mikhailov's favorite German poet was Heine, and he introduced the German author to Russian readers. However, his translation strategy towards Heine's originals underwent a certain change by the end of his life, as it has been pointed out by Levin: "Sometimes Mikhailov made digressions from the original and 'reworked' it according to his aims, [...] he introduced the translated book into the mainstream of the Russian civil poetry, making it weapon of revolutionary struggle" $(1985,212)$. Literary translation in the mid19th century in Russia acquired a dissident function, when the choice of books for translation was mostly determined by their critical pathos. Not surprisingly, Austen's novels did not meet the requirements, or, as Nepomnyashchy wrote, they were "not in the spirit of contemporary Russian literature: that is, of the novels that adopt strong social and political stances" $(2007,343)$. For the most part of the 20th century, the situation with Jane Austen in Russia remained unchanged. Pride and Prejudice 
was first translated into Russian by Immanuil Marshak in 1967, but the print run of the volume was 20,000 (not a very large one by late-Soviet standards), and it was published by an academic publishing house (the Academy of Sciences of the USSR), leaving the impression that "Austen remained largely the property of the hide-bound Soviet scholarly establishment; very much, that is, in the realm of the academic" (Nepomnyashchy 2007, 346).

Undoubtedly, there is a strong temptation to explain the case of Austen's absence in the Soviet Union by political reasons, namely, the oppressive domineering of the so-called socialist realism as the state-approved literary movement. Theresa M. Kenney has stated that "socialist realism was the only accepted artistic style in most communist countries: abstract impressionism, the bourgeois novel, love stories, domestic comedy - all were considered decadent if not counter-revolutionary" (2011, 117). From our point of view, this is only partly true - although Soviet literary history is full of real drama when the ideology suppressed creativity, the officialdom with its socialist realism theory did not fully subdue the real literary development. Austen's novels were not just disapproved of by the Soviet censors; they were generally overlooked by 19th-century Russian critics and translators. This attitude can be called public censorship and said to have originated in the 19th century. Therefore, the Soviet neglect can be logically viewed as a long-lasting reception tradition, a sort of belated inertia.

The neglect is visible not only in the absence of Austen's books in Russian, but also in the absence of her name in the Soviet textbooks on English literature, a situation that lasted almost to the end of the 20th century. When all her novels were finally translated into Russian in the 1980s, their appearance coincided with the global popularity of the film adaptation of the author's novels, so their reception history in Russia did not fully follow the route suggested by Nepomnyachshy: Austen's novels were appropriated by the mass culture almost immediately after their translation into Russian. Thus, Austen fell out of the Russian history of the English novel, which is clearly evidenced by the shortage, almost absence of scholarly research of her works in Russian (with a few exceptions). True, her works have found their way into contemporary Russian textbooks of English literature, but the process is far from being complete. Significantly, Austen's first biography in Russian was released only in 2013, when Colibry Publishers in Moscow released a translation of Claire Tomalin's Jane Austen: A Life, an acclaimed biography that had appeared in English in 1997. Thus, Jane Austen's belated translation played a curious trick on her prose reception in Russia.

\section{NON-TRANSLATION AND ITS CONSEQUENCES}

The case of Austen in Russia can vividly demonstrate that the non-translation of an important author or texts of fiction results in different consequences. First, the original national canon (English in this case) is distorted in the target (Russian) culture. Besides, the belatedly translated books of fiction are often displaced as compared with the place they occupy in the original canon, Jane Austen in Russian translation making a good example of the phenomenon.

Jane Austen was not the only leading English author of the 19th century whose books in translation were omitted by Russian translators - Emily Brontës novel 
Wuthering Heights (1847) appeared in Russian only in 1956. A similar absence, not only of individual English authors but of entire literary movements, can be clearly seen in 20th-century English literature in Russian translation. Translation/non-translation could be regarded as a canon-forming activity, as suggested by the contents of the textbook English Literature for high-school students by Martsella Hecker, Tatyana Volosova, and Alexander Doroshevich that reads in the following way (no omissions or changes):

Periods in English 20th century Literature

William Somerset Maugham. The Luncheon (the text of the short story is given unabridged)

Katherine Mansfield. A Cup of Tea (the text of the short story is given unabridged)

Richard Aldington. Death of a Hero

Archibald Joseph Cronin. The Citadel

Graham Greene. Life of Graham Greene. Literary work. The Quiet American

James Aldridge $(1975,175)$.

There are several points that attract the reader's attention: first, the names of all the English Modernists (Virginia Woolf, D.H. Lawrence, James Joyce) are left out and never mentioned in the book. Minor books by Lawrence and Joyce were first translated in the 1920s and 1930s, but then almost forgotten till the late 20th century, while Woolf's books came to Russian readers in the late 1980s and 1990s. What is more, in the textbook the names of the best-known authors (Graham Greene, who was much published and widely read in the USSR) go side by side with authors of modest achievement. Though James Aldridge was approved by the Soviet officialdom due to his political views, widely published, and awarded with the Lenin Prize in 1972, his books, probably except for The Last Inch, were never extremely popular with readers.

Sometimes the absence of translation that has long-lasting consequences can be explained, first and foremost, by political reasons. We will suggest some examples from American literature in Russian translation. The Civil War of 1861-1865 in the United States is considered one of the central events in the country's collective memory, where both sides, the Unionists and the Confederates, are present and reflected by their own images. During the American Civil War and immediately afterwards, the Russian intelligentsia and the public opinion ardently supported the Unionists (the North). The support applied to different spheres, including literature and translation, when books written from the Northern perspective were immediately translated and culturally appropriated, while the Southern perspective was rarely, if ever, mentioned. The famous anti-slavery novel Uncle Tom's Cabin by Harriet Beecher Stowe, which was first published in 1852, became immediately popular with Russian readers, first in the English original, and later in the Russian translation that followed in 1858. The translation was not easily published, since Russian censors found too many correlations between the novel's plot and the Russian peasant's revolts and disturbances the 1850s were turbulent years, when the Russian serfdom was much debated, which resulted in the abolition of serfdom in 1861. During the second half of the 19th and the 20th century, Uncle Tom's Cabin was translated into Russian several times, and its popularity constantly grew. By the late Soviet period, it reached the status of a his- 
torical novel that was well-known to the vast majority of Soviet young adult readers. Conversely, the Southern perspective was crystallized in the myth of the "Lost Cause", shaped Southern regional identity and was subsequently reflected in a number of works of fiction. The most famous, Gone with the Wind by Margaret Mitchell, appeared in print in 1936 and was an immediate and enormous success. Despite the worldwide fame, the novel did not appear in Russian translation by Tatiana Ozerskaya until 1991, a year after the release of the famous Hollywood adaptation Gone with the Wind dubbed into Russian. In the preface to the first Russian edition, the critic Peter Palievsky stated: “Scarlett O'Hara [...] has finally come to us dressed up in a new attire, which she liked so much - in the Russian language" $(1991,7){ }^{2}$ Thus, both the book and the film translation were delayed for more than half of a century after their creation. The delay can be explained by political preferences - e.g., the support of the North - and reasoning, but the result was obvious: the picture of the American literary development was distorted in the Russian perception.

\section{WHEN STATE INTERFERENCE INTO TRANSLATION CAN BE FRUITFUL: THE CASE OF WORLD LITERATURE PUBLISHERS}

At the same time, the state interference into translation policy was not always restrictive, as it is commonly thought. After the Russian Revolution of 1917, the famous writer and Lenin's close acquaintance Maxim Gorky put forward an idea of publishing a book series called Vsemirnaja literatura (World literature). For this large-scale undertaking a specialized publishing house was established in 1918 in Petrograd, with Lenin's approval and state financial support. According to the publishers' ideas, the new socialist world demanded new translations of the best books of the New Era - from 1789 (the French Revolution). Books of earlier periods were excluded from the list. The first catalog showcased books from almost all European countries, as well as from the USA, Canada, India, Argentina, Peru, etc. From these nations, almost 1,200 authors were represented. The leading Russian writers, literary critics, and translators worked under Gorky's leadership - new translations appeared and the first scholarly research on literary translation was produced. A number of theoretical articles on poetry translation were written by Nikolay Gumilev, a famous poet and translator, and Korney Chukovsky, a well-known critic, translator and children writer, published the first edition of his book on the theory of literary translation that was further reworked to become one of the most influential Russian books in the field, Vysokoe iskusstvo (The Art of Translation: Kornei Chukovsky's A High Art, 1964; Eng. trans. 1984).

Gorky's mass translation and publishing project got the following assessment from H.G. Wells, who visited the Soviet Union in 1920 and published his book Russia in the Shadows in 1921:

the bulk of the writers and artists have been found employment upon a grandiose scheme for the publication of a sort of Russian encyclopaedia of the literature of the world. In this strange Russia of conflict, cold, famine and pitiful privations there is actually going on now a literary task that would be inconceivable in the rich England and the rich America of today [...]. In starving Russia hundreds of people are working upon translations, 
and the books they translate are being set up and printed, work which may presently give a new Russia such a knowledge of world thought as no other people will possess. I have seen some of the books and the work going on (5).

By 1924, the publishing house was closed and Gorky left the country for Italy, 220 books and 11 journal issues had been published (see Khomitsky 2013). The Vsemirnaja literatura project was renewed in the late Soviet period, when the 200-volume series of world literature was published by the Khudozhestvennaya literatura publishing house (Moscow, 1967-1977, print run 300,000). The new series comprised translations of literary works from the ancient world to the 20th century. Though ideological approaches sometimes applied to the choice of books for translation, generally the project made an outstanding contribution to the Soviet and Russian history of translation. The role of the state was great and generally fruitful, though the very tradition of non-selection of certain books and authors could be seen in the choice of book titles.

\section{CONCLUSION}

The Russian history of translation underwent different stages and was much affected by factors of an external and internal character. Both selection and non-selection of books for translation have played an important role in In its early stages, the socalled literary transplantation played a fruitful role in the national literature development. Being transplanted into the Old Russian literature, Byzantine texts quickly formed models for further development of national literature. A typologically similar model of development was repeated in the 18th century, when secular translations of West European, particularly French books, contributed to laying the foundation for the New Russian literature. Starting from the late 18th and especially in the 19th century, the choice of books for translation played an increasingly significant role in the European canon-forming for Russian, and in many ways Soviet, readers as well. Translation demonstrated both politically affirmative and dissident functions, depending upon a combination of factors, where selection or non-selection of books for translation was essential. Social factors played an important role in Russian translation history; state interference into literary translation was not always negative, while public censorship had an ambivalent effect, as in the case of Austen in Russian. The results of the study show how non-translation of literary texts can distort the original literary canon of the source culture in the target culture reception. The case of translation of West European literature into Russian can demonstrate how the seemingly pure aesthetic field is involved into social (historic, political, ideological) life and determined by it. Hopefully, the further development of translation history will become more balanced if the correlation of what was translated and what was not will be properly taken into account.

\section{NOTES}

${ }^{1}$ Unless otherwise stated, all translations from Russian are by the present author.

2 The critic was right: the novel became immensely popular. 


\section{LITERATURE}

Berman, Antoine. 1984. L'Épreuve de l'étranger. Culture et traduction dans l'Allemagne romantique: Herder, Goethe, Schlegel, Novalis, Humboldt, Schleiermacher, Hölderlin. Paris: Gallimard.

Bellos, David. 2011. Is That a Fish in Your Ear? The Amazing Adventures of Translation. London: Penguin Books.

Chukovsky, Korney. 1964. Vyssokoye iskusstvo [The high art]. Moscow: Iskusstvo.

Even-Zohar, Itamar. [1990] 2004. “The Position of Translated Literature within the Literary Polysystem." In The Translation Studies Reader, Second ed., ed. by Lawrence Venuti, 199-204. New York, NY and London: Routledge.

Gifford, Henry. 1968. "Dickens in Russia: The Initial Phase." Forum for Modern Languages Studies 4, 1: 45-52. DOI: https://doi.org/10.1093/fmls/IV.1.45.

Hecker, Martsella, Tatyana Volosova, and Alexander Doroshevich. 1975. English Literature IX. Moscow: Prosveshcheniye.

Kenney, Theresa M. 2011. "Jane Austen, Revolution, Socialist Realism, and Reception: A Response to Helong Zhang's 'Jane Austen: 100 Years in China"' Persuasions: The Jane Austen Journal 33: 115122.

Khomitsky, Maria. 2013. "World Literature, Soviet Style: A Forgotten Episode in the History of the Idea." Ab Imperio 3: 119-154. DOI: https://doi.org/10.1353/imp.2013.0075.

Lefevere, André. [1982] 2004. "Mother Courage's Cucumbers: Text, System and Refraction in a Theory of Literature." In The Translation Studies Reader, Second ed., ed. by Lawrence Venuti, 238-255. New York and London: Routledge.

Levin, Yuri. 1985. Russkiye perevodchiki XIX veka [Russian translators of the 19th century]. Leningrad: Nauka.

Likhachev, Dmitry S. 1973. Razvitiye russkoi literatury X-XVII vekov: Epokhi i stili [Development of Russian literature in the 10th-17th centuries: The epochs and styles]. Leningrad: Nauka.

Nepomnyashchy, Catharine. 2007. "Jane Austen in Russia: Hidden Presence and Belated Bloom". In The Reception of Jane Austen in Europe, ed. by Anthony Mandal and Brian Southam, 334-349. London: Continuum.

Lotman, Yuri M. 1992a. "Neskolko mysley o tipologii kultur". In Izbranniye statji, Tom 1 [Selected articles, Vol. 1], Yuri Lotman, 102-109. Tallinn: Alexandra.

Lotman, Yuri M. 1992b. "K postroyeniu teorii vzaimodeistviya kultur (semiotichesky aspect)". In Izbranniye statji, Tom 1 [Selected Articles, Vol. 1], Yuri Lotman, 110-121. Tallinn: Alexandra.

Lotman, Yuri M. 1992c. “Jezda v ostrov lubvi Trediakovskogo i funktsii perevodnoy khudozhestvennoy literatury v Russkoy kulture pervoy poloviny XVIII veka”. In Izbranniye statji, Tom 2 [Selected articles, Vol. 2], Yuri Lotman, 22-29. Tallinn: Alexandra.

Palievsky, Piotr. 1991. "Margaret Mitchell i ejo kniga". In Unesennyie Vetrom, Margaret Mitchell, trans. by Tatiana Ozerskaya, 7-15. Moscow: Pravda.

Pasternak, Boris. 2004. "Zametki perevodchika (v poriadke obsuzhdeniya)". In Sobraniye sochinenii $v 11$ tomakh, Tom 5 [Collected works in 11 volumes, Vol. 5], Boris Pasternak, 51-54. Moscow: Slovo.

Pushkin, Alexander. 1963. "Count Nulin." In Sobraniye sochinenii v 10 tomakh, Tom 4 [Collected works in 10 volumes, Vol. 4], Alexander Pushkin, 237-250. Moscow: Academy of Sciences of the USSR Publishers.

Tomalin, Claire. 2013. Zhisn' Jane Austen. Trans. by Alina Deriglazova. Moscow: Colibri.

Volodarskaya, Ljudmila. 2004. "Tri vekhi v istorii russkogo poeticheskogo perevoda" [Three landmarks in the history of Russian poetic translation]. Toronto Slavic Quarterly 8 (Spring). Accessed March 20, 2021. http://sites.utoronto.ca/tsq/08/volodarskaya08.shtml.

Wells, Herbert George. 1921. "Russia in the Shadows." BooksCafe.Net. Accessed March 20, 2021. https:// bookscafe.net/read/wells_herbert-russia_in_the_shadows-216208.html\#p3. 
Literary transplantation. Selection/non-selection. Jane Austen. Canon-forming function. World literature translation project.

Russian and Soviet history of translation has undergone different stages of its development. Western literature in Russian translation played a significant role in forming the national literature (the so-called literary transplantation of the 18th century). Later, not only selection, but also non-selection of books/authors for translation played a canon-forming function. Social (historical, political, ideological) influence on translation was of a shifting nature, as it is shown by examples (such as Jane Austen). It also affected the process of selection/non-selection of books for translation.

\author{
Prof. Olga Sidorova, PhD, \\ Ural Federal University \\ 19 , Mira Str. \\ 620002 Yekaterinburg \\ Russia \\ o.g.sidorova@urfu.ru \\ ORCID: https://orcid.org/0000-0002-2813-7514
}

